УДК 616.311.2+616.314.17/.19)-08-053.81

DOI 10.11603/2311-9624.2020.1.12036

\author{
CН. І. Гелей ${ }^{2}$, М. А. Пасічник ${ }^{1}$, А. І. Фурдичко ${ }^{1}$, М. П. Ільчишинн ${ }^{1}$, I. I. Горбань ${ }^{1}$ \\ Львівський національний медичний університет імені Данила Галицького ${ }^{1}$ \\ ДВНЗ «Ужгородський національний університет»² \\ e-mail: immartella@gmail.com

\section{Результати використання запропонованої схеми лікування захворювань пародонта в осіб молодого віку}

\section{ІНФОРМАЦІЯ}

Надійшла до редакціі//Received: 27.01.2021 p.

Ключові слова: патологія пародонта; катаральний гінгівіт; генералізований пародонтит; загострення; рецидиви; бензидамін гідрохлорид.

\section{АНОТАЦІЯ}

Резюме. На сьогодні захворювання тканин пародонта переважають у структурі стоматологічної захворюваності, поширюючись в усіх вікових групах, мають агресивний перебіг із високою здатністю до частих загострень та рецидивів. Це викликає необхідність подальшої розробки та упровадження нових методів та схем місцевого та загального лікування захворювань пародонта із застосуванням різних медикаментозних засобів. Особливу увагу необхідно приділити медикаментам із нестероїдною протизапальною дією, серед яких виділяється препарат на основі бензидаміну гідрохлориду.

Мета дослідження - встановити ефективність запропонованої схеми терапії захворювань пародонта в осіб молодого віку.

Матеріали і методи. У дослідженні взяли участь 53 особи молодого віку хворі на хронічний катаральний гінгівіт та генералізований пародонтит початкового - І ступенів розвитку. Залежно від застосованих схем лікування, обстежуваних осіб поділили на дві групи. Усім хворим групи порівняння проводили лікування, передбачене Протоколом надання медичної допомоги за спеціальністю «Терапевтична стоматологія». Хворим основної групи, окрім базової терапії, застосовували запропоновану схему лікування, яка включала використання розчину для полоскання «Фортеза» та таблетки «Хлорофіліпт». Обстеження проводили до лікування, відразу після лікування та через 6 місяців після лікування.

Результати досліджень та їх обговорення. Гігієна ротової порожнини у хворих із патологією пародонта основної групи одразу після проведеного лікування суттєво покращилась і залишалась доброю упродовж півроку. В осіб із ХКГ та ГП початкового - І ступеня, до лікування яких входила запропонована схема, було виявлено кращий терапевтичний ефект як одразу після лікування, так і через 6 місяців після лікування, ніж у групі порівняння, про що засвідчили показники індексів PMA та PBI.

Висновки. Дані клінічних досліджень засвідчили суттєво кращі результати лікування захворювань пародонта у молодих осіб, при використанні розчину для полоскання «Фортеза» та таблеток «Хлорофіліпт», що підтверджено результатами гігієнічного та пародонтальних індексів відразу після лікування та через півроку після лікування 
Вступ. На сьогодні захворювання тканин пародонта переважають у структурі стоматологічної захворюваності, поширюючись в усіх вікових групах, мають агресивний перебіг із високою здатністю до частих загострень та рецидивів [7, 9-13]. Втрата зубів та порушення функціонування зубощелепної системи найчастіше пов'язані з захворюванням тканин пародонта, що становить не тільки медичну, але й соціальну проблему [1]. Поліфакторність розвитку захворювань пародонта, а саме вплив різноманітних екзогенних та ендогенних чинників, сприяє високій частоті виникнення цих захворювань в осіб працездатного віку й зниженню якості їхнього життя $[1,2,4]$. Хоча мікробний чинник відіграє основну роль в етіології патології пародонта та сприяє стану хронічної інтоксикації організму хворих, однак наявність супутніх захворювань послаблює резистентність організму та створює умови для активації пародонтопатогенної мікрофлори [3, 6, 8]. Використання розчинів для полоскання $є$ потужним профілактичним методом, який забезпечує позитивний як хімічний, так і механічний впливи на тканини пародонта. Існує великий арсенал розчинів для полоскання, які мають виражений терапевтичний вплив, а результати введення їх до схеми лікування захворювань пародонта вказують на стійкий та тривалий терапевтичний ефект. Особливу увагу в цій схемі потрібно приділити медикаментам із нестероїдною протизапальною дією, серед яких виділяється препарат на основі бензидаміну гідрохлориду, який має виражену протизапальну та місцеву анальгезуючу дію. Особливістю бензидаміну $є$ гальмування розвитку запалення у тканинах на найбільш ранніх етапах. Цей процес відбувається завдяки його здатності пригнічувати синтез прозапальних цитокинів та простагландинів [4, 5, 14-16].

Мета дослідження - встановити ефективність запропонованої схеми терапії захворювань пародонта в осіб молодого віку.

Матеріали і методи. У дослідженні взяли участь 53 особи молодого віку (віком від 20 до 40 років, чоловіків - 30 осіб, жінок - 23 особи) із захворюваннями пародонта, серед яких 28 хворих на хронічний катаральний гінгівіт (ХКГ), та 25 пацієнтів із генералізованим пародонтитом початкового - I ступенів розвитку (ГП поч. - I ст.). Обстеження проводили на базі Стоматологічного медичного центру Львівського національного медичного університету (ЛНМУ) імені Данила Галицького. Залежно від застосованих схем лікування, обстежуваних осіб поділили на дві групи. У групу порівняння увійшли 24 особи, а саме: група IA - 14 хворих на ХКГ, та група ІБ - 10 хворих на ГП поч. - I ст. Усім хворим групи порівняння проводили лікування, передбачене Протоколом надання медичної допомоги за спеціальністю «Терапевтична стоматологія». Основну групу, що становила 29 осіб, також було поділено на дві підгрупи, а саме: групу IIA - 14 хворих на ХКГ та групу ІІБ - 15 хворих на ГП поч. - І ст. Окрім базової терапії захворювань пародонта у хворих основної групи застосовували запропоновану схему лікування, яка включала використання розчину для полоскання «Фортеза» (АБДІ ІБРАХІМ Ілач Санаї ве Тіджарет А. Ш., Туреччина) тричі на день (з інтервалами 3-4 год), упродовж 20-30 с полоскати ротову порожнину 15 мл вказаного розчину, виплюнути рідину, тривалість застосування - 7 діб та таблетки «Хлорофіліпт» (ТОВ «Фармацевтична фірма «ВЕРТЕКС», Україна) по 1 таблетці 5 разів на добу, після споживання їжі, утримувати в ротовій порожнині до повного розсмоктування 5 днів при ХКГ та 7 днів при ГП поч. - I ст.

Обстеження пацієнтів включало в себе збір анамнезу, об’єктивне обстеження ротової порожнини: визначали індекс гігієни Гріна - Вермільйона (OHI-S, 1964), індекс гінгівіту (PMA, Parma, 1960) та індекс кровоточивості (PBI, 1977). Обстеження проводили до лікування, відразу після лікування та через 6 місяців після лікування. Статистичну обробку результатів власних досліджень здійснювали за допомогою комп’ютерної програми для варіаційно-статистичного аналізу даних медикобіологічних досліджень "Graph Pad Prism 5».

Результати досліджень та їх обговорення. Проведене лікування було ефективним у обох групах. Проте в основній групі результати клінічних досліджень були вірогідно кращими, порівняно з результатами групи порівняння, як одразу після лікування, так і через 6 місяців. Вихідні дані в обох груп не мали вірогідної різниці. У таблиці 1 наведено динаміку показників клінічних індексів у хворих на ХКГ у різні терміни лікування.

Гігієна ротової порожнини у хворих груп IA та IIA на початок дослідження була задовільною, а одразу після проведеного лікування суттєво $(\mathrm{p}<0,05)$ покращилась. Проте через півроку показники індексу OHI-S суттєво кращі були у хворих групи IIA і свідчили про 
Таблищя 1. Динаміка показників клінічних індексів у хворих на хронічний катаральний гінгівіт у різні терміни лікування $(\mathrm{M} \pm \mathrm{m})$

\begin{tabular}{|c|c|c|c|c|}
\hline \multirow{2}{*}{ Індекс } & Група & До лікування & $\begin{array}{c}\text { Відразу після } \\
\text { лікування }\end{array}$ & $\begin{array}{c}6 \text { місяців після } \\
\text { лікування }\end{array}$ \\
\hline \multirow{2}{*}{ ОНІ-S, бали } & IA (n=14) & $1,64 \pm 0,15$ & $0,46 \pm 0,04^{*}$ & $1,13 \pm 0,05^{*}$ \\
\cline { 2 - 5 } & IIA (n=10) & $1,60 \pm 0,13$ & $0,38 \pm 0,04^{*}$ & $0,41 \pm 0,03^{*} \#$ \\
\hline \multirow{2}{*}{ РМА, \% } & IA (n=14) & $22,71 \pm 1,6$ & $10,75 \pm 0,8^{*}$ & $18,45 \pm 1,0^{*}$ \\
\cline { 2 - 5 } & IIA (n=10) & $22,42 \pm 1,8$ & $8,22 \pm 0,7^{*}$ & $8,56 \pm 0,9^{*} \#$ \\
\hline \multirow{2}{*}{ PВI, бали } & IA (n=14) & $1,81 \pm 0,09$ & $0,12 \pm 0,01^{*}$ & $1,1 \pm 0,01^{*}$ \\
\cline { 2 - 5 } & IIA (n=10) & $1,78 \pm 0,08$ & $0,08 \pm 0,03^{*}$ & $0,16 \pm 0,03^{*} \#$ \\
\hline
\end{tabular}

Примітки: 1) * - показник вірогідності $(\mathrm{p}<0,05)$ порівняно з показниками до лікування;

2) \# - показник вірогідності $(\mathrm{p}<0,05)$ між показниками груп IA та IIA.

добру гігієну, а у хворих групи IА гігієна була задовільною.

У хворих на ХКГ основної групи одразу після лікування показник запалення РМА вірогідно знизився у 2,7 раза $(\mathrm{p}<0,05)$, а у групі порівняння - у 2,1 раза. Через півроку після проведеної терапії показники індексу РМА у хворих основної залишались на тому ж рівні, що й одразу після лікування, а у хворих групи порівняння зросли, хоча від даних до лікування все ще вірогідно відрізнялись.
Одразу після лікування результати індексу кровоточивості у хворих групи IA та IIA позитивно змінилися і значно різнилися $(\mathrm{p}<0,05)$ від даних до лікування. Через 6 місяців показники все ще суттєво відрізнялися від даних до лікування в обох групах, однак у хворих групи IIA у 11,1 раза, а у хворих групи IA - у 1,6 раза.

Результати дослідження хворих на ГП поч. - І ст. груп ІБ та ІІБ у різні терміни лікування наведені у таблиці 2.

Таблиця 2. Динаміка показників клінічних індексів у хворих на ГП поч. - І ст. у різні терміни лікування $(\mathrm{M} \pm \mathrm{m})$

\begin{tabular}{|c|c|c|c|c|}
\hline \multirow{2}{*}{ Індекс } & Група & До лікування & $\begin{array}{c}\text { Відразу після } \\
\text { лікування }\end{array}$ & $\begin{array}{c}6 \text { місяців після } \\
\text { лікування }\end{array}$ \\
\hline \multirow{2}{*}{ ОНІ-S, бали } & ІБ (n=14) & $2,63 \pm 0,21$ & $0,65 \pm 0,04^{*}$ & $1,96 \pm 0,11$ \\
\cline { 1 - 4 } & ІІБ (n=15) & $2,59 \pm 0,19$ & $0,43 \pm 0,01^{*}$ & $0,61 \pm 0,02^{* \#}$ \\
\hline \multirow{2}{*}{ РМА, \% } & ІБ (n=14) & $34,7 \pm 1,6$ & $13,6 \pm 1,0^{*}$ & $21,8 \pm 1,3^{*}$ \\
\cline { 2 - 5 } & ІІБ (n=15) & $35,2 \pm 1,4$ & $11,5 \pm 1,1^{*}$ & $12,3 \pm 1,1^{*} \#$ \\
\hline \multirow{2}{*}{ РВІ, бали } & ІБ (n=14) & $2,30 \pm 0,08$ & $0,17 \pm 0,01^{*}$ & $0,55 \pm 0,02^{*}$ \\
\cline { 2 - 5 } & ІІБ (n=15) & $2,28 \pm 0,08$ & $0,14 \pm 0,01^{*}$ & $0,16 \pm 0,01^{* \#}$ \\
\hline
\end{tabular}

Примітки: 1) * - показник вірогідності (p<0,05) порівняно з показниками до лікування;

2) \# - показник вірогідності (p<0,05) між показниками груп ІБ та ІІБ.

Індекс Гріна - Вермільйона у групі ІБ одразу після проведення базової терапії суттєво знизився у 4 рази $(\mathrm{p}<0,05)$, а через 6 місяці відрізнявся у 1,3 раза. У групі ІІБ показник одразу після лікування вірогідно різнився 3 даними до лікування у 6 разів $(\mathrm{p}<0,05)$ і через півроку гігієна ротової порожнини у цих хворих залишалась доброю, а показник різнився з даними групи ІБ у 3,2 раза.

Показники індексу запалення РМА у хворих груп ІБ та ІІБ після проведеної терапії знизились у 2,5 та 3,1 раза відповідно. Застосування в комплексній терапії захворювань пародонта препаратів «Фортеза» та «Хлорофіліпт» дало змогу досягнути стабільнішого результату, про що свідчать показники PMA отримані через 6 місяців після лікування, а саме істотна різниця даних у групі ІІБ у 2,9 раза відносно даних до лікування та в 1,8 раза кращий результат відносно групи ІБ.

В усіх хворих суттєво знизилась кровоточивість ясен, а саме, у 13,5 раза у групі ІБ та у 16,3 раза в групі ІІБ. Втім через півроку показники групи ІІБ були стабільними і вірогідно різни- 
лися $(\mathrm{p}<0,05) 3$ даними групи ІБ і становили $(0,16 \pm 0,01)$ бала та $(0,55 \pm 0,02)$ бала відповідно.

Висновки. Дані клінічних досліджень засвідчили суттєво кращі результати лікування захворювань пародонта у молодих осіб, при використанні розчину для полоскання «Фортеза» та таблеток "Хлорофіліпт», окрім базової терапії. Ефективність розробленої та застосованої схеми лікування підтверджується не тільки зникненням клінічних симптомів захворювання, а й тривалим стабільним лікувальним ефектом (упродовж півроку) як у хворих на хронічний катаральний гінгівіт, так і у хворих на генералізований пародонтит початкового - I ступеня розвитку захворювання.

Перспективою подальших досліджень $€$ розроблення ефективної схеми лікування захворювань пародонта в осіб молодого віку, при використанні антисептичних розчинів для полоскання та медикаментозної терапії.

\section{СН. И. Гелей${ }^{2}$ М. А. Пасечник ${ }^{1}$, А. И. Фурдычко ${ }^{1}$, М. П. Ильчишин ${ }^{1}$, И. И. Горбань ${ }^{1}$}

Львовский национальный медицинский университет имени Данила Галицкого 1 ГВУЗ «Ужгородский национальный университет»²

\section{Результаты использования предложенной схемы лечения заболеваний пародонта у лиц молодого возраста}

Резюме. На сегодня заболевания тканей пародонта преобладают в структуре стоматологической заболеваемости, распространяясь во всех возрастных группах, имеют агрессивное течение с высокой способностью к частым обострениям и рецидивам. Поэтому необходимо проводить дальнейшие разработки и внедрения новых методов и схем местного и общего лечения заболеваний пародонта с применением различных медикаментозных средств. Особое внимание следует уделить медикаментам с нестероидными противовоспалительным действием, среди которых выделяется препарат на основе бензидамина гидрохлорида.

Цель исследования - установить эффективность предложенной схемы терапии заболеваний пародонта у лиц молодого возраста.

Материалы и методы. В исследовании приняли участие 53 человека молодого возраста, больных хроническим катаральным гингивитом и генерализованным пародонтитом начальной - I степени развития. В зависимости от применяемых схем лечения, обследуемых лиц разделили на две группы. Всем больным группы сравнения проводили лечение, предусмотренное Протоколом оказания медицинской помощи по специальности «Терапевтическая стоматология». Больным основной группы кроме базовой терапии применяли предложенную схему лечения, которая включала использование раствора для полоскания «Фортеза» и таблетки «Хлорофиллипт». Обследование проводили до лечения, сразу после лечения и через 6 месяцев после лечения.

Результаты исследований и их обсуждение. Гигиена полости рта у больных с патологией пародонта основной группы сразу после лечения существенно улучшилась и оставалась хорошей в течение полугода. У лиц с ХКГ и ГП нач. - І ст., лечение которых включало предложенную схему, было обнаружено лучший терапевтический эффект как сразу после лечения, так и через 6 месяцев после лечения, нежели в группе сравнения, о чем свидетельствуют показатели индексов РМА и РВИ.

Выводы. Данные клинических исследований показали существенно лучшие результаты лечения заболеваний пародонта у молодых лиц, при использовании раствора для полоскания «Фортеза» и таблеток «Хлорофиллипт» кроме базовой терапии, что подтверждено результатами гигиенического и пародонтальных индексов сразу после лечения и через полгода после лечения.

Ключевые слова: патология пародонта; катаральный гингивит; генерализованный пародонтит; обострение; рецидивы; бензидамин гидрохлорид. 


\section{(C) I. Heley ${ }^{2}$ M. A. Pasichnyk ${ }^{1}$, A. I. Furdychko', M. P. Ilchyshyn ${ }^{1}$, I. I. Horban ${ }^{1}$ \\ Danylo Halytskyi Lviv National Medical University ${ }^{1}$ \\ Uzhhorod National University ${ }^{2}$ \\ Results of using the proposed treatment regimen for periodontal diseases in young people}

Summary. Today, periodontal diseases predominate in the structure of dental morbidity, spreading in all age groups, have an aggressive course with a high ability to frequent exacerbations and relapses. Therefore, it is necessary to further develop and implement new methods and schemes for local and general treatment of periodontal diseases with the use of various drugs. Particular attention should be paid to drugs with nonsteroidal anti-inflammatory action, among which stands out a medications based on benzydamine hydrochloride.

The aim of the study - to establish the effectiveness of the proposed scheme of treatment of periodontal disease in young people.

The study involved 53 young people with chronic catarrhal gingivitis and generalized periodontitis of initial - I degree of development. Depending on the treatment regimens, the subjects were divided into two groups. All patients in the comparison group underwent treatment provided by the Protocol of medical care in the specialty "Therapeutic Dentistry». In addition to basic therapy, patients in the main group received the proposed treatment regimen, which included the use of «Forteza» rinsing solution and «Chlorophyll» tablets. Examinations were performed before treatment, immediately after treatment and 6 months after treatment. Results and Discussion. Oral hygiene in patients with periodontal pathology of the main group immediately after treatment improved significantly and remained good for six months.

In persons with CCG and GP initial - I degree the treatment of which included the proposed scheme, showed a better therapeutic effect both immediately after treatment and 6 months after treatment than in the comparison group, as evidenced by the indicators of the indices of PMA and RVI.

Conclusions. Clinical studies have shown significantly better results in the treatment of periodontal disease in young people, using a rinsing solution "Forteza" and tablets "Chlorophyll", confirmed by hygienic and periodontal indices immediately after treatment and through six months after treatment.

Key words: periodontal pathology; catarrhal gingivitis; generalized periodontitis; exacerbations; recurrences; benzydamine hydrochloride.

\section{СПИСОК ЛІТЕРАТУРИ}

1. Клінічна оцінка застосування препаратів імуномодулюючої дії в комплексному лікуванні хворих 3 хронічним генералізованим пародонтитом початкового - І ступеня тяжкості / А. Я. Бариляк, М. П. Ільчишин, А. І. Фурдичко, І. Р. Федун // Новини стоматології. - 2015. - № 4. - С. 165-166.

2. Бандрівський Ю. Л. Ефективність лікувальних заходів за даними параклінічних індексів у хворих на генералізований пародонтит початкового - I ступеня, асоційована з груповою приналежністю крові / Ю. Л. Бандрівський // Клінічна стоматологія. - 2020. - № 2. - С. 14-23.

3. Гончарук Л. В. Взаимосвязь воспалительных заболеваний пародонта и соматической патологии / Л. В. Гончарук, К. Н. Косенко, С. Ф. Гончарук // Современная стоматология. - 2011. - № 1. - С. 37-40.

4. Данилевский Н. Ф. Заболевания пародонта / Н. Ф. Данилевский, А. В. Борисенко. - К. : Здоров’я, 2000. -466 с.

5. Гелей В. М. Застосування комплексного лікування дисбактеріозу слизової оболонки порожнини рота на фоні рефлюкс-езофагіту / В. М. Гелей, М. К. Добровольська, Н. I. Гелей // INTER Medical Journal. 2019. - № 1 (13). - С. 67-70.
6. Ільчишин М. П. Поширеність захворювань пародонту серед тютюнозалежних осіб / М. П. Ільчишин, А. І. Фурдичко, А. Я. Бариляк // Новини стоматології. - 2018. - № 4 (97). - С. 86-88.

7. Марушко Ю. В. Узагальнення даних застосування бензидаміну гідрохлориду та цетилпіридинію хлориду в клінічній практиці / Ю. В. Марушко, А. О. Асонов // Современная педиатрия. - 2018. - № 7 (95). - C. 83-87.

8. Пасічник М. А. Корекція методики застосування тіотріазоліном в комплексному лікуванні генералізованого пародонтиту на тлі соматичної патології : матеріали наук.-практ. конф. «Клінічна та профілактична медицина» / М. А. Пасічник, I. I. Ногачевська-Горбань, А. І. Фурдичко. - 2019. - № 3-4 (9-10). - С. 153.

9. Самойленко А. В. Сучасні аспекти етіології, патогенезу та лікування різних клінічних варіантів генералізованого пародонтиту : автореф. дис. на здобуття наук. ступеня д-ра. мед. наук : спец. 14.01.22 / А. В. Самойленко. - Одеса, 2003. - 34 с.

10. Холодняк О. В. Ефективність лікування локалізованих захворювань тканин пародонта в осіб молодого віку за показниками дослідження швидкості 
салівації та стану кислотно-лужного балансу в порожнині рота / О. В. Холодняк, М. К. Добровольська // Клінічна стоматологія. - 2015. - № 3-4. - С. 46-52.

11. Шевчук М. М. Стоматологічний статус у пацієнтів Львівської обласної клінічної лікарні 3 дистрофічно-запальними захворюваннями тканин пародонта / М. М. Шевчук // Клінічна стоматологія. - 2018. - № 4. - C. 36-42.

12. Determination of individual cephalometric characteristics of the occlusal plane in Ukrainian young men and young women with orthognatic bite / M. O. Dmitriev, I. V. Gunas, I. V. Dzevulska, I. V. Zhulkevych // Biomedical and Biosocial Anthropology. - 2018. - No. 33. - P. 5-11. DOI: 10.31393/ bba33-2018-01.

13. Correspondence between dental and skeletal maturity parameters among patients with different

\section{REFERENCES}

1. Baryliak, A.Ya., Ilchyshyn, M.P., Furdychko, A.I., \& Fedun, I.R. (2015). Klinichna otsinka zastosuvannia preparativ imunomoduliuiuchoi dii v kompleksnomu likuvanni khvorykh z khronichnym heneralizovanym parodontytom pochatkovoho - I stupenia tiazhkosti [Clinical evaluation of the use of immunomodulatory drugs in the complex treatment of patients with chronic generalized periodontitis of the initial - I degree of severity]. Novyny stomatolohii - News of Dentistry, 4, 165-166 [in Ukrainian].

2. Bandrivskyi, Yu.L. (2020). Efektyvnist likuvalnykh zakhodiv za danymy paraklinichnykh indeksiv $u$ khvorykh na heneralizovanyi parodontyt pochatkovoho - I stupenia, asotsiiovana z hrupovoiu prynalezhnistiu krovi [Efficacy of treatment measures according to paraclinical indices in patients with generalized periodontitis initial and first degrees of severity, depending on the blood group]. Klinichna stomatolohiia - Clinical Dentistry, 2, 14-23 [in Ukrainian].

3. Goncharuk, L.V., Kosenko, K.N., \& Goncharuk, S.F. (2011). Vzaimosvyaz vospalitelnykh zabolevaniy parodonta i somaticheskoy patologii [Interrelation of inflammatory periodontal diseases and somatic pathology]. Sovremennaya stomatologiya - Modern Dentistry, 1, 37-40 [in Russian].

4. Danilevskiy, N.F., \& Borisenko, A.V. (2000). Zabolevaniya parodonta [Periodontal disease]. Kyiv: Zdorovia [in Ukrainian].

5. Heley, V.M., Dobrovolska, M.K., \& Heley, N.I. (2019). Zastosuvannia kompleksnoho likuvannia dysbakteriozu slyzovoi obolonky porozhnyny rota na foni refliuks-ezofahitu [The use of complex treatment of dysbacteriosis of the oral mucosa on the background of reflux esophagitis]. INTER Medical Journal, 1 (13), 67-70 [in Ukrainian].

6. Ilchyshyn, M.P., Furdychko, A.I., \& Baryliak, A.Ya. (2018). Poshyrenist zakhvoriuvan parodontu sered tiutiunozalezhnykh osib [Prevalence of periodontal diseases among tobacco-dependent persons]. Novyny stomatolohii - News of Dentistry, 4 (97), 86-88 [in Ukrainian].

7. Marushko, Yu.V., \& Asonov, A.O. (2018). Uzahalnennia danykh zastosuvannia benzydaminu hidrokhlorydu sagittal relationships at the end of puberty period / M. Goncharuk-Khomyn, E. Akleyin [et al.] // J. Int. Dent. Med. Res. - 2020. - Vol. 13 (1). - P. 223-228.

14. Papapanou P. N. Periodontitis epidemiology: is periodontitis under-recognized, over-diagnosed, or both? / P. N. Papapanou, C. Susin // Periodontology 2000. - 2017. - Vol. 75 (1). - P. 45-51.

15. Prevalence of the generalized periodontitis in patients with different groups blood in depending on age and periodontal biotype / Yu. L. Bandrivsky, O. O. Bandrivska, R. Yu. Shkrebnyuk, V. T. Dyryk // Wiadomości Lekarskie. - 2020. - No 1 (73) - P. 119-1222. 16. Treatment of generalized periodontitis in patients with general-somatic pathology of the digestive system / N. I. Heley, Ye. Ya. Kostenko, M. K. Dobrovolska, V. M. Heley // INTER Medical Journal. - 2017. - No 2 (10). - P. 42-45.

ta tsetylpirydyniiu khlorydu $\mathrm{v}$ klinichnii praktytsi [Generalization of data on the use of benzydamine hydrochloride and cetylpyridinium chloride in clinical practice]. Sovremennaya pediatriia-Modern Pediatrics, 7 (95), 83-87 [in Ukrainian].

8. Pasichnyk, M.A., Nohachevska-Horban, I.I., \& Furdychko, A.I. (2019). Korektsiia metodyky zastosuvannia tiotriazolinom $\mathrm{v}$ kompleksnomu likuvanni heneralizovanoho parodontytu na tli somatychnoyi patolohii [Correction of the method of application of thiotriazoline in the complex treatment of generalized periodontitis on the background of somatic pathology]. Proceedings of the Scientific and Practical Conference "Klinichna ta profilaktychna medytsyna»"Clinical and preventive medicine», 3-4 (9-10), 153 [in Ukrainian].

9. Samoylenko, A.V. (2003). Suchasni aspekty etiolohii, patohenezu ta likuvannia riznykh klinichnykh variantiv heneralizovanoho parodontytu [Modern aspects of etiology, pathogenesis and treatment of various clinical variants of generalized periodontitis]. Doctor's thesis. Odesa [in Ukrainian].

10. Kholodnyak, O.V., \& Dobrovolska, M.K. (2015). Efektyvnist likuvannia lokalizovanykh zakhvoriuvan tkanyn parodonta v osib molodoho viku za pokaznykamy doslidzhennia shvydkosti salivatsii ta stanu kyslotnoluzhnoho balansu v porozhnyni rota [Effectiveness of treatment of localized diseases of parodont tissues in young people by the indices of the research of salivation speed and the state of acid base balance of oral cavity]. Klinichna stomatolohiia - Clinical Dentistry, 3-4, 46-52 [in Ukrainian].

11. Shevchuk, M.M. (2018). Stomatolohichnyi status $\mathrm{u}$ patsiientiv Lvivskoi oblasnoi klinichnoi likarni $\mathrm{z}$ dystrofichno-zapalnymy zakhvoriuvanniamy tkanyn parodonta [Stomatological status in patients of the Lviv regional clinical hospital with distrophic-inflammatory diseases of periodontal tissues]. Klinichna stomatolohiia - Clinical Dentistry, 4, 36-42 [in Ukrainian].

12. Dmitriev, M.O., Gunas, I.V., Dzevulska, I.V., \& Zhulkevych, I.V. (2018). Determination of individual cephalometric characteristics of the occlusal plane in Ukrainian young men and young women with 


\section{Терапевтична стоматологія}

orthognatic bite. Biomedical and Biosocial Anthropology, 33, 5-11. DOI: 10.31393/bba33-2018-01

13. Goncharuk-Khomyn, M., Akleyin, E., Zhulkevych, I., Nahirnyi, Y., Brekhlichuk, P., Mochalov, Y., \& Stoika, O. (2020). Correspondence between dental and skeletal maturity parameters among patients with different sagittal relationships at the end of puberty period. J. Int. Dent. Med. Res., 13 (1), 223-228.

14. Papapanou, P.N., \& Susin, C. (2017). Periodontitis epidemiology: is periodontitis under-recognized, overdiagnosed, or both? Periodontology 2000, 75 (1), 45-51. DOI: $10.1111 /$ prd.12200
15. Bandrivsky, Yu.L., Bandrivska, O.O., Shkrebniuk, R.Yu., \& Dyryk, V.T. (2020). Prevalence of the generalized periodontitis in patients with different groups blood in depending on age and periodontal biotype. Wiadomości Lekarskie, 1 (73), 119-1222.

16. Heley, N.I., Kostenko, Ye.Ya., Dobrovolska, M.K., \& Heley, V.M. (2017). Treatment of generalized periodontitis in patients with general-somatic pathology of the digestive system. INTER Medical Journal, 2 (10), $42-45$. 